\title{
Do workers act contentment?
}

\author{
Lukertina \\ Fakultas Ekonomi dan Bisnis, Universitas Mercu Buana
}

\begin{abstract}
This paper aims to identify the determine job satisfaction on employee for the continuity of business in the field of rental of workspace, and at same time to determine the effect of work discipline and work motivation on employee satisfaction. Data was collected via survey questionnaire from related literature to 70 respondents. The data analyzed using structural equation modeling via Smart PLS. The results showed a significantly positive between the work discipline on the job satisfaction, but not for the work motivation on the job satisfaction.
\end{abstract}

Keywords: Job satisfaction, work discipline, work motivation, rental workspace, human resources

DOI: $10.7176 / \mathrm{JRDM} / 56-07$

Publication date:June $30^{\text {th }} 2019$

\section{Introduction}

One of the determinants of the sustainability of a business in global competition is creating high-quality, skilled, and highly competitive human resources. Effective employees are needed to face the increasingly stringent global market competencies. Employees can work effectively when they have satisfaction and enthusiasm. The company's ability to earn profits to improve company performance is supported by financial and intellectual capital. Improved performance of Human Resources is influenced by employee satisfaction, while job satisfaction is subjective because one of them is derived from within employees such as IQ or intelligence. Intellectual capital (IC) has become a concern because there is a combination of human capital, structure capital, and customer capital. Intellectual capital in a company can improve the company's financial performance; increasing profitability can be done through investment in the field of human resources (Kurniasih and Heliantono, 2016).

Organizations that want to get big profits need more collaboration between management and employees (Lukertina, 2018). Every individual who works in an organization wants to get a benefit, and feeling satisfied or dissatisfied with the conditions of their work environment will affect their work. (Saluy and Treshia, 2018). Companies need to provide guidance, secure facilities, and training to improve performance (Magito, 2018). The decline in performance in the office management business was caused by an increase in the number of customer complaints which resulted in inconvenience for customers as tenants of office space.

According to Robbins and Coulter (2016), job satisfaction tends to lead to attitude, not behavior; like always being present, having a high work ethic, and being loyal to the organization. Attitudes are evaluative statements related to objects, people or events. Attitudes consist of three components (cognition, affect and behavior). The cognitive component is an attitude that consists of beliefs, opinions, knowledge or information that a person has. Affective components are emotions or feelings. Behavior is a component that refers to the intention to behave in a certain way towards someone or something. Job satisfaction is combination of employee feelings toward the different facets of such as the nature of the work itself, level of pay, promotion, opportunities, and satisfaction with coworker (Maurya \& Agarwal, 2017).

In fact, Walker (2003) identified six ways of in which discipline matrix can contribute to the overall goals of police disciplinary systems: first, communicating the values of the agency; second, ensuring accountability by specifying minimum discipline; third, ensuring appropriate discipline; four, ensuring consistency in discipline; five, ensuring fairness in discipline; and six, ensuring accountability for command officers. According to Haris CJ et al (2015) “ .... disciplinary action would be for a particular act of misconduct. Even in individual cases, imposed discipline is often not made public, or is specifically forbidden by law or union contracts". However, Yunus (2014) state of the employee work discipline is a thing that shows employee attitudes and behavior towards work; this means that employees have a commitment to the rules that apply in the organization. Discipline formed in employees reflects responsibility in carrying out their duties and jobs so that they can increase enthusiasm and job satisfaction in achieving organizational goals.

Rivai (2015) said the discipline is a component used by managers to communicate with employees so that they are willing to change behavior and components used to increase awareness and willingness to comply with applicable company regulations and social norms. Poor condition of service, late payment of salaries, workplace 
harassment, lack of trust, or lack of supervisor support is responsible for quitting a job and decreasing job satisfaction (Maurya \& Agarwal, 2013a, b,2014, 2015)

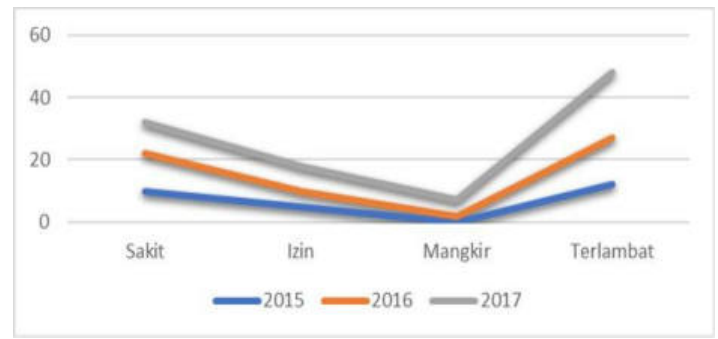

Figure 2. Attendance Chart

Robbins and Coulter (2016), motivation is the process of achieving a goal through directed and sustained effort and energy. Strength (intensity) shows how hard the effort. Great power cannot provide satisfactory results without direction. Persistence measures how long a person can maintain his efforts. Fajana (2002) added that motivation is of two kinds namely, positive motivation is seen when people behave according to what is expected by the society, and negative motivation is doing wrong things which are kicked against by the society. In addition, there are motivating factors that will lead to library personnel satisfaction and increased motivation. Examples are achievement, recognition, advancement and work it. The success of any university library depends on the effectiveness of employee's job performance which to a large extent depends on the level of skill acquisition, experience and motivation among other factors.

Kolawole, Abolaji and Olagoke (2015) defined motivation as an incentive given by the employer to employees to enable them perform their jobs creditably, while Strough, Bruine de Bruin and Peters (2015) referred to motivation as the willingness to engage with a decision, including considering the presented information, deliberating about the options, and selecting the option that is most likely to lead to preferred outcomes. According to Safiullah, (2015) motivation is an index of inner feeling in a certain way to the need of the individual that jobs must be designed to further employee's performance and fulfillment. Motivation is internal and external factors that stimulate desire and energy in people to be continually interested in and committed to a job, role, or subject, and to exert persistent effort in attaining a goal (Onyeukwu and Ekere, 2018). According to Safiullah, (2015) motivation is an index of inner feeling in a certain way to the need of the individual that jobs must be designed to further employee's performance and fulfillment.

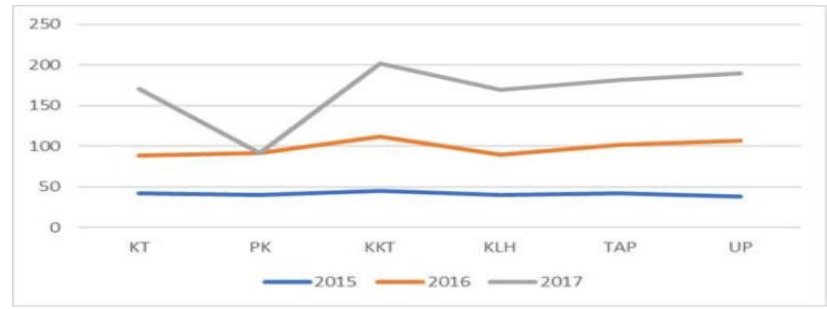

Figure 1. Complaint Graph

Descriptions:

$\mathrm{UP}=$ Hot Air (Irregular Service)

TAP $=$ There are no officers when needed

$\mathrm{KLH}=$ Floor and yard cleanliness

$\mathrm{KKT}=$ Cleanliness and comfort of the toilet

PK = Handling complaints in a timely manner

$\mathrm{KT}=$ Not responsive

\section{Literature Review}

\subsection{Work Discipline and Job Satisfaction}

The results of the study by Nalapraya et al. (2018) showed that work discipline has a significant effect on job satisfaction. According to Idris et al. (2018), they found a positive and significant influence of work motivation on employee job satisfaction. It is also Siallagan et al (2016); Tanjung (2017) find the work discipline 
has a positive and significant effect on job satisfaction. Whereas according to Lianasari et al. (2017) the work discipline has no effect on job satisfaction.

$H 1=$ Work discipline is positively related to job satisfaction

\subsection{Work Motivation and Job Satisfaction}

Motivation to lead was a significantly positive correlate of job satisfaction (Maurya \& Agarwal, 2017). The results of the study by Lumentut et al (2015); Now (2016); Yusra et al. (2017); Alhamdi (2018) showed that work motivation has a significant effect on job satisfaction. According to Helmida (2018), if the company wants to achieve optimal performance according to its intended target, the company must provide motivation to employees so that employees get satisfaction so they want and are willing to devote their energy and mind to work. This is also in accordance with the results of a study conducted by Suwarto (2014) that showed that work motivation has a significant effect on job satisfaction, whereas according to research by Ariani and Assarofa (2018), work motivation has a positive but not significant effect.

$H 2=$ Work Motivation is positively related to job satisfaction

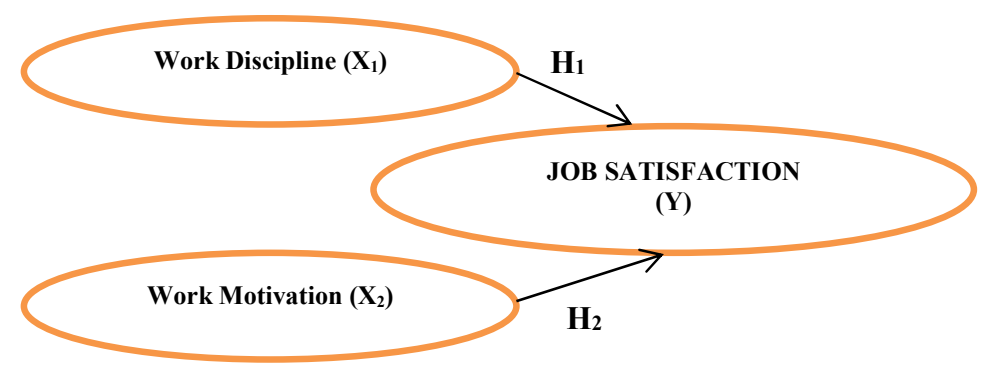

Figure 3.Research framework

\section{Method}

According the total populations are 70 employees, and the questionaires have been sent to all. The questionaires was divided into three sections, first is work discipline consist of 10 items from 5 dimension, adapted from Rivai (2015); second is work motivation consist of 15 items from 5 dimension, adapted from Robbins and Judge (2015); and the last is job satisfaction consist of 12 items from 5 dimension, adapted from Robbins and Judge (2015). Each item was obtained based on a 5-point Likert-type Scale. Figure 3 shows the schema of this research framework

\section{Results}

The Smart PLS version 3.0 and two-step analysis approach as suggested by Gerbing and Anderson (1988) were adopted to analyze the data.

\subsection{Convergent validity}

According to Chin in Ghozali (2014), indicators are said to have "good" validity if the value is $>0.70$, while loading factors from 0.50 to 0.60 can be considered "moderate". Based on these criteria, loading factors below 0.50 will be removed from the model. For all, the item loading exceeded the recommended value 0.6. The factor loadings, composite reliability and average variance extracted were indicator used to assess the convergent validity. As shown in Table 1 . 
Table 1. Factor loadings and reliability

\begin{tabular}{|c|c|c|c|c|}
\hline & Loading $^{\alpha}$ & CR & AVE & Cronbach $\alpha$ \\
\hline $\begin{array}{l}\text { DK.2 } \\
\text { DK.3 }\end{array}$ & $\begin{array}{l}0,898 \\
0,878\end{array}$ & - & - & \multirow{5}{*}{0,913} \\
\hline DK. 4 & 0,884 & \multirow{4}{*}{0,930} & \multirow{4}{*}{0,629} & \\
\hline $\begin{array}{l}\text { DK. } 5 \\
\text { DK. } 6\end{array}$ & $\begin{array}{l}0,640 \\
0,767\end{array}$ & & & \\
\hline $\begin{array}{l}\text { DK. } 7 \\
\text { DK } 9\end{array}$ & 0,882 & & & \\
\hline $\begin{array}{l}\text { DK.9 } \\
\text { DK. } 10\end{array}$ & $\begin{array}{l}0,537 \\
0,783\end{array}$ & & & \\
\hline $\begin{array}{l}K K K .1 \\
K K K\end{array}$ & $\begin{array}{l}0,863 \\
0,913\end{array}$ & \multirow{4}{*}{0,930} & - & \multirow{4}{*}{0,911} \\
\hline $\mathrm{KK} . \mathrm{S}$ & 0,621 & & \multirow{3}{*}{0,630} & \\
\hline $\begin{array}{l}\text { KK.6.6 } \\
\text { KK.7 }\end{array}$ & $=\begin{array}{l}0,600 \\
0,763\end{array}$ & & & \\
\hline KK. 8 & $=0.723$ & & & \\
\hline KK 12 & $=\begin{array}{l}0,916 \\
\quad 0,879\end{array}$ & & & \\
\hline $\begin{array}{l}\text { M.1 } \\
\text { M.3 }\end{array}$ & $\begin{array}{l}0,864 \\
0,843\end{array}$ & \multirow{6}{*}{0,934} & \multirow{6}{*}{0,588} & \multirow{6}{*}{0,923} \\
\hline $\begin{array}{l}\text { M.6 } \\
M .7\end{array}$ & 0,743 & & & \\
\hline M.10 & $\begin{array}{l}0,682 \\
0,669\end{array}$ & & & \\
\hline M.11 & $\begin{array}{l}0,874 \\
0,822\end{array}$ & & & \\
\hline M.13 & 0,802 & & & \\
\hline $\begin{array}{l}\text { M.14 } \\
\text { M.15 }\end{array}$ & $\begin{array}{l}0,637 \\
0,685\end{array}$ & & & \\
\hline
\end{tabular}

\subsection{Discriminant validity}

Discriminant validity, reflective indicators can be seen in cross-loading between indicators and their constructs. An indicator can be declared valid if it has the highest loading factor in the intended construct compared to loading factors to other constructs. Thus, latent constructs predict indicators on their blocks better than indicators in other blocks. Discriminant validity can be examined by comparing the square correlations between the constructs and the variance extracted for construct (Fornell and Larcker, 1981). As shown in Table 2.

Table 2. Discriminant Validity (Fornell-Lacker Criterium)

\begin{tabular}{|c|c|c|c|}
\hline & Discipline & $\begin{array}{c}\text { Employee } \\
\text { satisfaction }\end{array}$ & Motivation \\
\hline Discipline & 0.793 & & \\
\hline Employee satisfaction & 0.740 & 0.762 & \\
\hline Motivation & $-0,387$ & $-0,279$ & 0.719 \\
\hline
\end{tabular}

\subsection{Structural Model}

Based on Table 3, it can be concluded that Adjusted R-square value is 0.534 , which means that the variability of employee satisfaction can be explained by discipline and motivation variables is $53.4 \%$, while the remaining $46.6 \%$ is explained by other variables not examined in this model. The estimated value for track relationships in the structural model must be significant. Significance values can be obtained through bootstrapping procedures. Hypothesis significance can be known from the value of the parameter coefficient and T-statistic significance value on the algorithm bootstrapping report. Significance can be seen from the T-table at alpha $0.05(5 \%)=1.96$ and T-table compared to T-count (T-statistic).

Table 3. R-square Adjusted

\begin{tabular}{cc}
\hline Variabel Endogen & R-square Adjusted \\
\hline Employee satisfaction & 0.534 \\
\hline source : Output PLS, 2019 &
\end{tabular}

Table 4. Summary of the structural model

\begin{tabular}{lccl}
\hline & Original Sample & T- Statistics & Results \\
\hline Discipline $\rightarrow$ Employee satisfaction & 0.743 & 12.708 & Support \\
$\begin{array}{l}\text { Motivation } \rightarrow \text { Employee } \\
\text { satisfaction }\end{array}$ & 0.008 & 0.096 & Rejected \\
\hline
\end{tabular}

source : Output PLS, 2019 


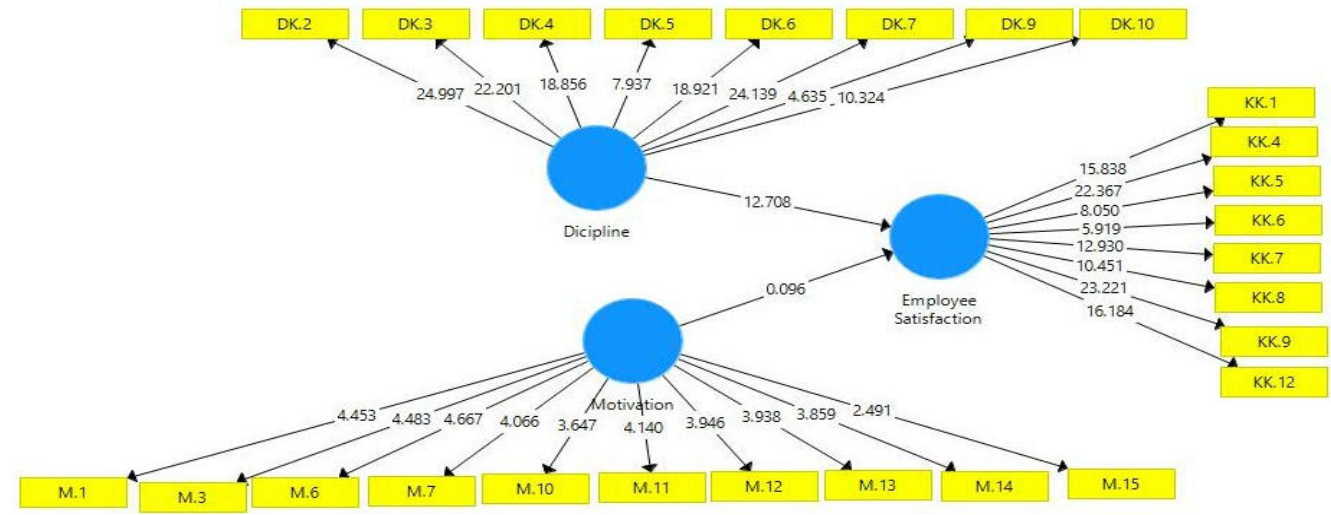

Figure 4. The structural model

\section{Discussion}

Discipline affects employee job satisfaction. This can be seen from the decrease in attendance rates and the increase in customer complaints that affect the performance of the employee and organization. Poor condition of service, late payment of salaries, workplace harassment, lack of trust, or lack of supervisor support is responsible for quitting a job and decreasing job satisfaction (Maurya \& Agarwal, 2013a, b, 2014, 2015). Discipline has a significant effect on job satisfaction, according to the Siallagan et al (2016) study; Tanjung (2017); Nalapraya et al. (2018).

Motivation has no affects on employee job satisfaction, according to Robbins and Coulter (2016), motivation is the process of achieving a goal through directed and sustained effort and energy. Persistence measures how long a person can maintain his efforts so giving more technical training or compensation cannot change the situation. Motivation does not have a significant effect on job satisfaction, according to the research of Ariani and Assarofa (2018).

Internal organizational problems can be overcome by giving penalties to employees who violate organizational rules. The execution of the sentence must be preceded by a stamped statement for each employee who works for the organization. Furthermore, organizations can establish external strategies to improve organizational performance

\section{References:}

Alhamdi, Rezki. 2018. Pengaruh Kompetensi Dan Motivasi Terhadap Kinerja Karyawan Dengan Kepuasan Kerja Sebagai Variable Moderasi di Patra Semarang Convention Hotel. Jurnal Pariwisata Pesona Vol 3 No 1 Hal 57-68 Online ISSN: 2541-5859 DOI: Prefix 10.26905

Ariani, Hj. Misna dan Assarofa, Abdurrahman. 2018. Pengaruh Motivasi, Disiplin dan lingkungan kerja terhadap kepuasan kerja karyawan pada PT Palma Plantasindo di desa Sunge Batu Kec Pasir Belengkong Kab Paser. Conference on Management and Behavioral Studies Universitas Tarumanagara ISSN 2541-3406

Fajana, S. 2002. Human Resource Management: An Introduction. Labofin and Company, Lagos.

Fornell, C. and Larcker, D.F. 1981. Evaluation structural equation models with unobserved variables and measurement error. Journal Market Research, 18(1), 39-50.

Gerbing, D.W. and Anderson, J.C. 1988. An updated paradigm for scale development incorporating unidimentional and its assessment. Journal of Marketing Research, 25, 186-192.

Ghozali, 2014. Structural Equation Modeling, Metode Alternatif dengan Partial Least Square (PLS). Edisi 4. Badan Penerbit Universitas Diponegoro. Semarang.

Helmida, Baiq E. and Irianto. 2018. Pengaruh Motivasi Dan Lingkungan Kerja Terhadap Kinerja Melalui Kepuasan Kerja Karyawan Pada AJB Bumiputera 1912 Cabang Mataram. Valid. Vol. 15, No. 1, hal. 2129.

Idris, idris et al. 2018. Determinants of employee work satisfaction. International Review of Management and Marketing, 2018, 8(6), 47-52. DOI: https://doi.org/10.32479/irmm.7187

Kolawole, J.A. et al. 2015. "Motivation and information management as a tool of job satisfaction of employees in Nigeria". African Journal of Business Management. Vol. 9(19), pp. 680-687 
Kurniasih, Augustina and Heliantono. 2016. Intellectual capital Bank BUMN Terbuka dan pengaruhnya terhadap kinerja perusahaan. MIX: Jurnal Ilmiah Manajemen, Volume 6, No.2, Juni 2016, pp.195212.

Lianasari et al. 2017. Pengaruh Stres Kerja, Employee Engagement Dan Kedisiplinan Terhadap Kinerja Dengan Kepuasan Kerja Sebagai Variabel Intervening Pada Karyawan CV. Karya Manunggal Semarang. Neo-Bis Vol. 11, No. 2, Desember 2017.

Lukertina. 2018. Pengaruh Budaya organisasi dan Gaya kepemimpinan terhadap kinerja karyawan. Jurnal Ilmiah Manajemen Bisnis, Volume 4, No.2, Juli 2018, pp. 224-240.

Lumentut, Mauritz D.S and Dotulong, Lucky O.H. 2015. Pengaruh Motivasi, Disiplin, dan Lingkungan Kerja Terhadap Kepuasan Kerja Karyawan Pada PT. Bank SULUT Cabang Airmadidi. Jurnal Emba: Jurnal Riset Ekonomi, Manajemen, Bisnis dan Akuntansi Vol 3 No 1 Hal 72-85, ISSN 2303-1174

Magito. 2018. Pengaruh Kepemimpinan Dan Motivasi Terhadap Kinerja Karyawan di PT. United Can Company. Jurnal Ilmiah Manajemen Bisnis, Volume 4, No. 02, Juli 2018, pp. 249 - 261.

Maurya, M.K. and Agarwal, M. 2013a. Relationship between interpersonal trust dimensions, mental health status and job satisfaction of PAC, civil police and traffic police. Indian Journal of Health and Wellbeing 4(4):785-789

Maurya, M.K. and Agarwal, M. 2013b. 'Motivation to lead' among male and female police constables. Journal of Psychosocial Research 8(1):13-21

Maurya, M.K. and Agarwal, M. 2014. Relationship between perceived workplace harassment, mental health status and job satisfaction of male and female civil pólice constables. Indian Journal of Community Psychology 10(1):162-177

Maurya, M.K. and Agarwal, M. 2015. Relationship between supportive leadership, mental health status and job satisfaction of male and female civil police constables. Journal of the Indian Academy of Applied Psychology 41(3):103-111

Maurya, M.K. and Agarwal, M. 2017. Relationship Between Motivation to Lead, Mental Health Status, and Job Satisfaction of Male and Female Civil Police Constables. J Police Crim Psych (2018) 33:9-20 DOI 10.1007/s11896-017-9230-4

Nalapraya et al. 2018. Pengaruh Disiplin Kerja Dan Budaya Organisasi Terhadap Kepuasan Kerja Dalam Meningkatkan Produktivitas Pegawai PDAM Tirta Indragiri Tembilahan. Jurnal Tepak Manajemen Bisnis. Vol. X, No.1.

Onyeukwu, P.E and Ekere, N.E. 2018. Evaluation of Staff Motivation Strategies on the Productivity of Nigerian Banking Industry. International Journal of Innovation and Economic Development Volume 4, Issue $1 \mathrm{Pp}$ 51-59

Rivai, Veithzal. 2015. Manajemen Sumber Daya Manusia untuk Perusahaan: dari Teori ke Praktik. Raja Grafindo Persada. Jakarta.

Robbins, Stephen P and Coulter, Mary. 2016. Manajemen Edisi 13. Salemba Empat. Jakarta

Robbins, Stephen P and Judge, Timothy A. 2015. Perilaku Organisasi Edisi 16. Salemba Empat. Jakarta

Safiullah, Ayesha Binte. 2015." Employee Motivation and its Most Influential Factors: A study on the Telecommunication Industry in Bangladesh.” World Journal of Social Sciences Vol.5 No. 1 Pp. 79 - 92

Saluy, A.B., Treshia, Y. 2018. Pengaruh motivasi kerja, disiplin kerja dan kompensasi terhadap kinerja karyawan (studi kasus di perusahaan PT.IE). Jurnal Ilmiah Manajemen and Bisnis, 2(1), 53-70.

Sekartini, Ni Luh . 2016. Pengaruh Kemampuan Kerja, Disiplin Kerja, Motivasi Kerja Terhadap Kepuasan Kerja dan Kinerja Karyawan Administrasi Universitas Warmadewa. Jurnal Ekonomi dan Bisnis Jagaditha Vol 3, No 2, Hal 64-75, ISSN: 2355-4150 DOI: 10.22225/jj.3.2.130.64-75

Siallagan, Hotriana et al. 2016. Pengaruh Gaya Kepemimpinan Dan Disiplin Kerja Terhadap Kepuasan Kerja Karyawan Pada PT. Telekomunikasi Indonesia, Tbk Witel Sumut Pematang Siantar. Jurnal Maker Vol. 2, No. 2, Desember 2016 ISSN : 2502-4434

Strough J, Bruine de Bruin W and Peters E. 2015. "New perspectives for motivating better decisions in older adults." Front. Psychol. 6:783. Doi: 10.3389/fpsyg

Suwarto. 2014. Pengaruh Stres Kerja Dan Motivasi Kerja terhadap Kepuasan Kerja Karyawan PT. Sorini Agro Asia Corporindo Tbk Cabang Lampung. Derivatif Jurnal Manajemen. Vol. 8, No. 2, ISSN: 1978-6573.

Tanjung, Hasrudi. 2017. Pengaruh Disiplin Kerja, Kompetensi dan Budaya Organisasi Terhadap Kepuasan Kerja Pegawai Pada Dinas Perkebunan Sumatera Utara. Jurnal Konsep Bisnis dan Manajemen Vol 3 No 1 Hal 111-122 ISSN :2407-2648

Walker, S. (2003), The Discipline Matrix: An Effective Police Accountability Tool?, Police Professionalism Initiative, Omaha, NB. 
Yunus, Alamsyah and Bachri, Ahmad A. 2014. Pengaruh Disiplin Kerja, Motivasi, Kepemimpinan Terhadap Kepuasan Kerja Karyawan Studi Pada PT Bumi Barito Utama Cabang Banjarmasin. Jurnal Wawadan Manajemen. Vol. 1, No. 2.

Yusra, et al. 2017. Pengaruh Motivasi Kerja, Pengembangan Karir Dan Komitmen Organisasi Terhadap Organizational Citizenship Behavior Pegawai Badan Pusat Statistik Provinsi Aceh Dengan Kepuasan Kerja Sebagai Variabel Intervening. Jurnal Manajemen Indonesia (J-Mind) Vol. 2, No. 1, 2017 P-ISSN : 2503-4367 